Arq. Bras. Med. Vet. Zootec., v.72, n.5, p.2001-2006, 2020

\title{
Communication
}

[Comunicação]

\section{Direct PCR of lesions suggestive of sporotrichosis in felines}

\author{
[PCR direta de lesões sugestivas de esporotricose em gatos] \\ F.F. Gonsales ${ }^{1}$, N.C.C.A. Fernandes ${ }^{2}$, W. Mansho ${ }^{3}$, H. Montenegro ${ }^{4}$, N.R. Benites ${ }^{5}$ \\ ${ }^{1}$ Faculdade de Zootecnia e Engenharia de Alimentos - Universidade de São Paulo - Pirassununga, SP \\ ${ }^{2}$ Instituto Aldofo Lutz - São Paulo, SP \\ ${ }^{3}$ Centro de Controle de Zoonoses de Guarulhos - Garulhos, SP \\ ${ }^{4}$ Centro de Controle de Zoonoses de São Paulo - São Paulo, SP \\ ${ }^{5}$ Faculdade de Medicina Veterinária e Zootecnia - Universidade de São Paulo - São Paulo, SP
}

Sporotrichosis is a zoonotic mycosis present in urban centers in Brazil (Montenegro et al., 2014; Gremião et al., 2017); the agent is often acquired by traumatic inoculation of the skin (Kauffman, 1999). Cases of human sporotrichosis have been reported in 14 of 26 Brazilian states, and the southern and southeast regions of Brazil have the highest incidence of human cases (Rodrigues et al., 2014). According to Pereira et al. (2014), sporotrichosis is considered a neglected disease and was a serious public health problem in Rio de Janeiro; from 1997 to 2011, 4118 human cases diagnosed at the INI/FIOCRUZ (Instituto Nacional de Infectologia Evandro Chagas/ Fundação Oswaldo Cruz), the main reference center for the treatment of this ringworm in Brazil (Silva et al., 2013; Gremião et al., 2015). In the last 3 years the city of Guarulhos has registered more than 1500 cases in cats, resulting in a status of "compulsory notification".

The known pathogenic species of Sporothrix are S. schenckii s. str., S. brasiliensis, S. globosa, $S$. mexicana, and S. lurei (Marimon et al., 2007); among these species, S. brasiliensis has been described as the most pathogenic (Marimon et al., 2007; Rodrigues et al., 2013) and geographically not only restricted to Brazil, some cases have already been described in Argentina (Córdoba et al., 2018; Etchecopaz et al., 2019). Epidemiological studies have indicated that $S$. brasiliensis is dependent on a feline host for its development in southern and southeastern Brazil (Rodrigues et al., 2014, 2013).

Recebido em 14 outubro de 2019

Aceito em 25 de maio de 2020

E-mail: fe.gonsales@gmail.com
Diagnosis and treatment delays in infected cats can lead to the rapid spread of the disease among animals and community members (Schubach et al., 2005). Therefore, it is fundamental to confirm sporotrichosis in a particular region for adequate public health planning. Direct PCR analysis of lesions in cats could expedite the diagnosis, initiation of treatment and other measures to control the disease; however, this method has not yet been described.

The definitive diagnosis depends on the isolation of the etiologic agent in culture (Silva et al., 2015). Other methodologies proposed for diagnosis are cytopathology (Pereira et al., 2011), histopathology (Miranda et al., 2013), serology (Fernandes et al., 2011), species determination by polymerase chain reaction of fungal isolation (Rodrigues et al., 2015) and cell block cytology (Gonsales et al., 2019). The aim of this study was to detect and identify the species of Sporothrix in cats with lesions from an endemic area and for whom sporotrichosis was part of the differential diagnosis (city of Guarulhos) and compare this method with the reference methodology, fungal culture, considering the following variables: type of injury (dry or wet) and treatment status of the cat (being treated or not treated) at the time of sampling.

Samples from skin lesions from 70 cats (28 (40\%) female and $42(60 \%)$ male) from Guarulhos city $\left(23^{\circ} 27^{\prime} 49^{\prime \prime S} 46^{\circ} 32^{\prime} 1 " \mathrm{~W}\right)$ were collected for culture and PCR analysis. Regarding the type of injury, there were $9(12.9 \%)$ dry lesions and 61 
(87.1\%) wet lesions. Sixteen $(22.9 \%)$ cats had already started treatment with itraconazole at the time of sampling, one of the cats had 1 week of treatment and the others had months of treatment (ranging from 2 to 9 months). The protocol was approved by the institutional ethics committee (FMVZ/USP ${ }^{\circ}$ 7029080616). Lesion samples for culture and PCR were collected with sterile swabs. Samples for culture were stored in Stuart's medium, and samples for PCR were stored in dry tubes without medium.

The cultures were seeded on Sabouraud agar with chloramphenicol and incubated at $30^{\circ} \mathrm{C}$ for 7 days, with growth observed and thermal reversal performed. Subsequently, a slide stained with lactophenol was prepared for microscopic confirmation of the genus; the visualization of septate hyphae with the typical aspect of daisy sporulation confirmed the genus (Hoog et al., 2000).

DNA from the obtained samples was extracted and purified using a DNeasy Blood and Tissue kit (Qiagen, Crawley, UK), following the manufacturer's instructions, resulting in DNA eluted in $200 \mu \mathrm{l}$ of buffer at the end of the process. To identify the Sporothrix species (S. schenckii s.s., S. brasiliensis, or S. globosa), the calmodulin locus region was amplified directly from genomic DNA PCR using primers and protocol described by Rodrigues et al. (2015). DNA concentration was determined with a NanoDrop 2000 spectrophotometer (Thermo Fischer Scientific, USA); ranging from 5.7 to $156.7 \mathrm{ng} / \mu \mathrm{l}$. The PCR mixture consisted of a $25 \mu \mathrm{L}$ final volume containing $12.5 \mu \mathrm{L}$ of Master Mix buffer for PCR (2X), $1 \mu \mathrm{L}$ of each specific primer (sense and antisense $-10 \mathrm{pmol} / \mu \mathrm{L}$ ) per reaction, $1 \mu \mathrm{L}$ of target DNA $(100 \mathrm{ng} / \mu \mathrm{l})$ and pure water to the final volume.

The conditions for the PCR were as follows: initial denaturation for 5 minutes at $95^{\circ} \mathrm{C}$, followed by 35 cycles of 1 minute at $95^{\circ} \mathrm{C}$, temperature annealing for 1 minute (touchdown PCR) and 1 minute at $72^{\circ} \mathrm{C}$. In the touchdown protocol, the annealing temperature was reduced by $1{ }^{\circ} \mathrm{C}$ every 2 cycles for 20 cycles; finally, the PCR was completed with an annealing temperature of $60^{\circ} \mathrm{C}$ for 15 cycles (Rodrigues et al., 2015). The amplification product together with a marker of molecular weight was subjected to agarose gel electrophoresis at $1 \%$ containing $0.1 \mu \mathrm{g}$ ethidium bromide per $\mathrm{mL}$ and visualized through an ultraviolet image capture system (Figure 1).

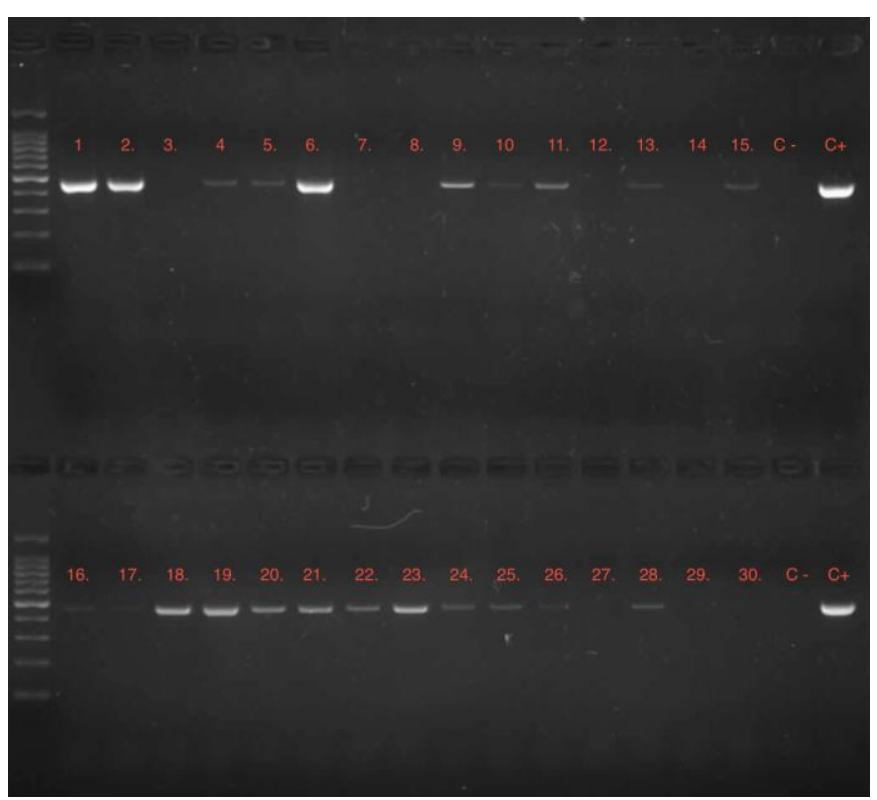

Figure 1. Agarose gel electrophoresis revealing amplicon sizes (469 base pairs) for S. brasiliensis. Numbers 1 to 30 refer to clinical samples of cats with suspected sporotrichosis lesion. $\mathrm{C}+=$ positive control; $\mathrm{C}-=$ negative control 
The results presented in Table 1 show that 61 of 70 cases (which corresponds to $87.1 \%$ ) were positive for Sporothrix by PCR or fungal culture. Also, 57 of 70 cases (which corresponds to $81.4 \%$ ) were positive for $S$. brasiliensis by PCR. It was also possible to check that 50 of 70 samples (which corresponds to $71.4 \%$ ) were positive by isolation and 46 of 70 (which corresponds to
$65.7 \%$ ) were positive by both methods. A total of 9 of 70 (which corresponds to $12.9 \%$ ) cases were negative by both methods; finally, we can highlight that 7 of 9 (which corresponds to $77.8 \%$ ) samples were taken from dry lesions, and 2 of 9 (which corresponds to $22.2 \%$ ) samples were taken from wet lesions.

Table 1. Results from PCR and isolation technique and respective kappa agreement values for the samples obtained from dry or wet skin lesions, and in the presence or absence of the initiated treatment with itraconazole (at the time of collection) of cats with suspected sporotrichosis

\begin{tabular}{llllllllll}
\hline & \multicolumn{2}{c}{$\begin{array}{c}\text { PCR } \\
\text { Isolation }+\end{array}$} & \multicolumn{2}{c}{$\begin{array}{c}\text { PCR }+ \\
\text { Isolation - }\end{array}$} & $\begin{array}{c}\text { PCR- } \\
\text { Isolation }+\end{array}$ & $\begin{array}{c}\text { PCR- } \\
\text { Isolation - }\end{array}$ & Kappa (CI) \\
\hline Overall & 46 & $65.7 \%$ & 11 & $15.7 \%$ & 4 & $5.7 \%$ & 9 & $12.9 \%$ & $0.413(0.173$ to 0.654$)$ \\
Treated & 4 & $5.7 \%$ & 7 & $10 \%$ & 0 & 0 & 5 & $7.1 \%$ & $0.263(-0.014$ to 0.540$)$ \\
Untreated & 42 & $59.9 \%$ & 4 & $5.7 \%$ & 4 & $5.7 \%$ & 4 & $5.7 \%$ & $0.413(0.077$ to 0.749$)$ \\
Dry lesion & 2 & $2.9 \%$ & 1 & $1.4 \%$ & 2 & $2.9 \%$ & 4 & $5.7 \%$ & $0.308(-0.307$ to 0.922$)$ \\
Wet lesion & 44 & $62.9 \%$ & 10 & $14.3 \%$ & 2 & $2.9 \%$ & 5 & $7.1 \%$ & $0.353(0.079$ to 0.628$)$ \\
\hline
\end{tabular}

$+=$ positive; $-=$ negative; $C$ I confidence interval

Wet lesions had a significantly higher positive rate for $S$. brasiliensis than dry lesions $(\mathrm{P}<0.01)$ according to PCR. Sixteen sampled cats had already begun treatment with itraconazole without a previous diagnosis; $15(93.7 \%)$ of them presented wet lesions, and 11/15 (73.3\%) samples were confirmed $S$. brasiliensis-positive by PCR. The remaining cat had dry lesions, and the sample was confirmed as $S$. brasiliensis-positive by PCR. There were $65.7 \%$ coincident results between both methods (kappa $=0.413$ ), indicating moderate agreement. The treated group presented less agreement than the untreated group, mainly due to false negative culture results.

Regarding the overall frequencies of the results analyzed in this study, an increased frequency of positive results was observed in cats with wet lesions that had not yet begun treatment with itraconazole at the time of sampling. This result is similar to the double positivity results considering both methods (PCR and fungal isolation), which showed an increased frequency $(65.7 \%)$ in cats with wet lesions that were untreated; these frequencies were much higher than those of the other parameters analyzed $(\mathrm{P}<0.0001)$.

Among the cases that were positive only by PCR, 4 were from treated cats and 2 were from dry lesions. Although there was no significant difference between the groups $(\mathrm{P}>0.05), \mathrm{PCR}$ may be an alternative for diagnosing felines.
Eleven results were PCR positive but with negative fungal isolation, all of these samples were from wet skin lesions. From these, 7 cats were already under the effect of itraconazole. A hypothesis for this result is that the medication has interfered with fungal growth; in the case of the other 4 cats, it could be explained by the higher sensitivity of PCR: it detects a low amount of the agent, without the need for fungal viability. On the other hand, 4 cats were $S$. brasiliensis-negative by PCR with fungal isolation; 2 of dry and 2 of wet skin lesion samples. A conjecture that could justify this result is the limitation of a speciesspecific primer, like the one adopted in this study, that couldn't detect a different Sporothrix species. In this way, we didn't achieve an amplified DNA for sequencing, limiting the diagnosis.

Usually, species determination of Sporothrix is achieved after fungal isolation and growth. Direct PCR can increase the speed of the results and avoid these intermediate steps. The majority of evaluated cases were positive by both methods, and $23.9 \%$ of positive samples were detected by only PCR, which is a method with high sensitivity. A total of $8.7 \%$ samples were positive by only culture, which may suggest that fungal pathogen culture isolation has a lower sensitivity than PCR (Kumar and Mugunthan, 2018). Clinicians report a difficult time in diagnosing sporotrichosis from dry lesions, as it is difficult to obtain culture and cytology results. Although there is no data in the literature on diagnosis rates 
from wet and dry lesions, we tested this hypothesis; we did not observe any significant difference among dry and wet lesions. PCR had a higher frequency of positive results than culture in the studied groups, and studies with a larger sample size than the current one may help verify this possibility.

In conclusion, direct PCR of lesions suggestive of sporotrichosis in cats was a good method to confirm and identify species of Sporothrix, allowing for rapid diagnosis and achieving good agreement with fungal isolation. Parameters such as lesion presentation (wet or dry) and whether or not the treatment had been initiated interfered with the detection of S. brasiliensis, as well as the isolation of Sporothrix spp

Keywords: zoonosis, Sporothrix brasiliensis, molecular diagnosis, cats

\section{RESUMO}

A esporotricose é uma doença emergente e a incidência de esporotricose zoonótica tem aumentado, principalmente no Brasil; a maioria dos casos está relacionada à transmissão de gatos infectados. $O$ diagnóstico definitivo da esporotricose felina é feito por cultura fúngica; no entanto, aguardar o longo período de cultura pode atrasar o início do tratamento. O objetivo deste estudo foi detectar e determinar as espécies de Sporothrix por PCR realizado diretamente das lesões de gatos, provenientes de área endêmica, nos quais a esporotricose fazia parte do diagnóstico diferencial. Um total de 87,1\% dos casos foi positivo por PCR ou cultura fúngica para Sporothrix; 81,4\% foram confirmados como $\mathrm{S}$. brasiliensis por PCR, 71,4\% por isolamento e 65,7\% pelos dois métodos. Em conclusão, a análise direta por PCR de lesões sugestivas de esporotricose em gatos é um bom método para confirmar a infecção e determinar as espécies de Sporothrix, garantindo um diagnóstico rápido; esse método tem uma boa concordância com o isolamento fúngico.

Palavras-chave: zoonose, Sporothrix brasiliensis, diagnóstico molecular, gatos

\section{REFERENCES}

CÓRDOBA, S.; ISLA, G.; SZUSZ, W. et al. Molecular identification and susceptibility profile of Sporothrix schenckii sensu lato isolated in Argentina. Mycoses, v.7, p.441-448, 2018.

ETCHECOPAZ, A.N.; LANZA, N.; TOSCANINI, M.A. et al. Sporotrichosis caused by Sporothrix brasiliensis in Argentina: case report, molecular identification and in vitro susceptibility pattern to antifungal drugs. $J$. Mycol. Med., v.30, 2019

FERNANDES, G.F.; LOPES-BEZERRA, L.M.; BERNARDES-ENGEMANN, A.R. et al. Serodiagnosis of sporotrichosis infection in cats by enzyme-linked immunosorbent assay using a specific antigen, SsCBF, and crude exoantigens. Vet. Microbiol, v.147, p.445-449. 2011.

GONSALES, F.F.; FERNANDES, N.C.CA.; MANSHO, W. et al. Feline Sporothrix spp. detection using cell blocks from brushings and fine-needle aspirates: performance and comparisons with culture and histopathology. Vet. Clin. Pathol., v.48, p.143-147, 2019.
GREMIÃO, I.D.F.; MENEZES, R.C.; SCHUBACH, T.M.P. et al. Feline sporotrichosis: Epidemiological and clinical aspects. Med. Mycol., v.53, p.15-22, 2015.

GREMIÃO, I.D.; MIRANDA, L.H.; REIS, E.G. et al. Zoonotic epidemic of sporotrichosis: cat to human transmission. PLoS Pathog., v.13, p.1-7, 2017.

HOOG, G.S.; QUEIROZ-TELLES, F.; HAASE, G. et al. Black fungi: clinical and pathogenic approaches. Med. Mycol., v.38, p.243-250, 2000.

KAUFFMAN, C.A. Sporotrichosis. Clin. Infect. Dis., v.29, p.231-237, 1999.

KUMAR, M.; MUGUNTHAN, M. Evaluation of three DNA extraction methods from fungal cultures. Med. J. Armed. Forces India, v.74, p.333-336, 2018.

MARIMON, R.; CANO, J.; GENÉ, J. et al. Sporothrix brasiliensis, S. globosa, and $S$. Mexicana, three new Sporothrix species of clinical interest. J. Clin. Microbiol., v.45, p.31983206, 2007. 
MIRANDA, L.H.M.; CONCEIÇÃO-SILVA, F.; QUINTELLA, L.P. et al. Feline sporotrichosis: histopathological profile of cutaneous lesions and their correlation with clinical presentation. Comp. Immunol. Microbiol. Infect. Dis., v.36, p.425-432, 2013.

MONTENEGRO, H.; RODRIGUES, A.M.S.; DIAS, M.A.G. et al. Feline sporotrichosis due to Sporothrix brasiliensis: an emerging animal infection in São Paulo, Brazil. BMC Vet. Res., v.10, p.1-10, 2014.

PEREIRA, S.A.; GREMIÃO, I.D.F.; KITADA, A.A.B. et al. The epidemiological scenario of feline sporotrichosis in Rio de Janeiro, State of Rio de Janeiro, Brazil. Rev. Soc. Bras. Med. Trop., v.47, p.392-393, 2014.

PEREIRA, S.A.; MENEZES, R.C.; GREMIÃO, I.D.F. et al. Sensitivity of cytopathological examination in the diagnosis of feline sporotrichosis. J. Feline Med. Surg.,_v.13, p.220223. 2011

RODRIGUES, A.M.; HOOG, G.S.; CAMARGO, Z.P. Molecular diagnosis of pathogenic Sporothrix Species. PLoS Neglected Trop. Dis., v.9, p.1-22, 2015.
RODRIGUES, A.M.; HOOG, G.S.; ZHANG, Y. et al. Emerging sporotrichosis is driven by clonal and recombinant Sporothrix species. Emerg. Microbes Infect., v.3, p.1-10, 2014.

RODRIGUES, A.M.; MELO, M.; HOOG, G.S. et al. Phylogenetic analysis reveals a high prevalence of Sporothrix brasiliensis in feline sporotrichosis outbreaks. PLoS Neglected Trop. Dis., v.7, p.1-14, 2013.

SCHUBACH, A.O.; SCHUBACH, T.M.; BARROS, M.B. Epidemic cat-transmitted sporotrichosis. N. Engl. J. Med. v.15, p.11851186, 2005.

SILVA, E.A.; BERNARDI, F.; SCHOENDORF, L.M.P. et al. Esporotricose: surto epidêmico com acometimento humano e felino na Zona Leste de São Paulo, Brasil. Acta Sci. Vet., v.41, p.11411144, 2013.

SILVA, J.N.; PASSOS, S.; MENEZES, R.C. et al. Diagnostic accuracy assessment of cytopathological examination of feline sporotrichosis. Med. Mycol., v.53, p.880-884, 2015. 